Karol Król

Uniwersytet Rolniczy w Krakowie

e-mail:k.krol@ur.krakow.pl

Krzysztof Gawroński

Uniwersytet Rolniczy w Krakowie

e-mail: k.gawronski@ur.krakow.pl

\title{
ANALIZA DZIAŁALNOŚCI SAMORZĄDOWYCH KOLEGIÓW ODWOŁAWCZYCH W POLSCE W LATACH 2012-2015
}

\section{Abstract \\ Analysis of Local Government Appeal Boards' Activity in Poland in the Years 2012-2015}

Local Government Boards of Appeals are bodies of higher instance as compared to agencies of territorial government units unless the specific acts legislate otherwise. The Boards are a specific guarantor of citizens rights protection and also rights for good administration. The aim of the paper is to analyse the activity of Local Government Boards of Appeals in Poland in the years 2012-2015. The method of descriptive and logical analysis was used in the paper. Annual reports of the activity of every Local Government Board of Appeals in Poland in the years 2012-2015 made up the starting material. In conclusion of performed surveys, the authors stated among others that in the examined period fluctuations of the number of cases coming into the Boards of Appeals were observed and the performed analysis allows to predict in the following years the number of submitted cases at the level of about 200,000. Moreover, in view of great amount of cases examined by Local Government Boards of Appeals in Poland, their financial support as well as employment increase are advisable.

Keywords: public administration, Local Government Boards of Appeals, administrative proceedings

\section{Streszczenie}

Samorządowe kolegia odwoławcze są organami wyższego stopnia w stosunku do organów jednostek samorządu terytorialnego, chyba że ustawy szczególne stanowią inaczej. Kolegia są gwarantem ochrony praw obywateli, a także prawa do dobrej administracji. Celem pracy jest analiza działalności samorządowych kolegiów odwoławczych w Polsce w latach 2012-2015. 
W pracy zastosowano metodę analizy opisowo-logicznej. Materiał wyjściowy stanowiły informacje roczne z działalności kolegiów.

W badanym okresie zaobserwowano m.in. wahania liczby spraw wpływających do kolegiów, a przeprowadzona analiza pozwala prognozować w kolejnych latach wpływ spraw na poziomie około 200 tysięcy rocznie. Ponadto badania pokazują, że od 2012 roku składy orzekające kolegiów potrzebują coraz więcej czasu na załatwienie sprawy. Zgłaszają przy tym coraz większy stopień skomplikowania spraw.

Słowa kluczowe: administracja publiczna, kolegia odwoławcze, postępowanie administracyjne

\section{Wstęp}

Gmina jest podstawową jednostką podziału terytorialnego. Stanowi rdzeń systemu samorządowego i realizuje zadania publiczne w celu zapewnienia odpowiedniego poziomu rozwoju społeczno-gospodarczego. Pełni jednocześnie funkcję jednego z filarów ustrojowych państwa polskiego [Glumińska-Pawlic, 2003; Satoła, 2010].

Gmina jako organ administracji publicznej działa na podstawie przepisów prawa. W toku postępowania stoi na straży praworządności, z urzędu lub na wniosek stron podejmuje czynności niezbędne do dokładnego wyjaśnienia stanu faktycznego oraz do załatwienia sprawy, mając na względzie interes społeczny i słuszny interes obywateli [Ustawa, 1960, art. 6, 7].

Postępowanie administracyjne jest wszczynane i prowadzone w celu załatwienia indywidualnej sprawy administracyjnej przez właściwy organ administracji publicznej. Władztwo administracyjne gminy jest realizowane m.in. za pomocą decyzji administracyjnych, chyba że przepisy prawa stanowią inaczej. Decyzje rozstrzygają sprawę co do jej istoty w całości lub w części, albo w inny sposób kończą sprawę w danej instancji [Ziniewicz, 2010]. Postępowanie administracyjne jest dwuinstancyjne - każda sprawa administracyjna rozpoznana i rozstrzygnięta decyzją organu pierwszej instancji powinna podlegać w toku odwołania ponownemu rozpoznaniu i rozstrzygnięciu przez organ drugiej instancji [Skibiński, 2008; Miłek, 2015]. Organami wyższego stopnia w stosunku do organów jednostek samorządu terytorialnego są samorządowe kolegia odwoławcze (SKO), chyba że ustawy szczególne stanowią inaczej [Ustawa, 1960, art. 17].

Kolegia zobowiązane są do prowadzenia ksiąg i innych urządzeń ewidencyjnych oraz sporządzania rocznych informacji o swojej działalności. Roczna informacja o działalności kolegium jest przyjmowana przez zgromadzenie ogólne kolegium.

Roczne informacje sporządzane przez samorządowe kolegia odwoławcze stanowią swoiste kompendium wiedzy o ich potencjale, zarówno dla samych kolegiów, jak i dla Prezesa Rady Ministrów. Wiedza taka, o słabościach i siłach danego układu organizacyjnego czy systemu, może mieć fundamentalne znaczenie dla jakości strategicznego planowania działań modernizacyjnych [Olejniczak, 2009]. Celem niniejszej pracy jest analiza działalności samorządowych kolegiów odwoławczych w Polsce w latach 2012-2015. 


\section{Zarządzanie w organizacjach publicznych}

Zarządzanie publiczne można rozpatrywać jako: aktywność służb publicznych oraz pochodzących z wyboru polityków; zestaw działań zarządczych odnoszących się do publicznych struktur władz wykonawczych i procesów realizowanych przez te władze; zarządzanie organizacjami publicznymi lub systemem organizacji publicznych, a także jako subdyscyplinę nauki o zarządzaniu [Kożuch, 2004; Kożuch, 2005; Cyfert et al, 2014]. Zarządzanie publiczne stanowi proces informacyjno-decyzyjny realizowany na różnych poziomach struktury organizacyjnej państwa jako całości, obejmujący też jednostki samorządu terytorialnego [Glińska et al, 1996].

Dotychczas nauki o zarządzaniu w niewielkim stopniu koncentrowały swój wysiłek badawczy na sferze publicznej, co powodowało swoistą asymetrię w rozwoju zarządzania na korzyść przedsiębiorstw [Kożuch, 2004]. Nastawienie nauk o zarządzaniu na rozwiązywanie problemów organizacji publicznych wymaga znacznego wysiłku. Występuje tu konieczność adaptacji wielu metod zarządzania z biznesu do instytucji publicznych [Sudoł, 2013]. Zarządzanie publiczne jest przedmiotem zainteresowania nie tylko nauk o zarządzaniu oraz ekonomii, ale również nauk o administracji, politologii czy też socjologii [Szumowski, 2014]. Podmioty publiczne i zarządzanie publiczne mogą być badane z różnych perspektyw, wchodzą bowiem w zakres zainteresowań różnych dyscyplin naukowych, takich jak ekonomia, politologia, prawo administracyjne, administracja publiczna, zarządzanie ogólne oraz teoria organizacji [Frączkiewicz-Wronka, 2013].

Rola, jaką odgrywa współcześnie administracja publiczna, jest znacząca [Izdebski, 2007]. Globalizacja gospodarki, postęp techniczny oraz zmiany w dynamice rynku postawiły nowe wyzwania organizacjom publicznym, które stanęły przed koniecznością weryfikacji dotychczasowego podejścia do zarządzania. Zaproponowane w latach 90 . zmiany w zarządzaniu podmiotami publicznymi na nowo zdefiniowały zadania i funkcje sektora publicznego. Wymogły także wykorzystanie nowoczesnych narzędzi zarządczych w działaniach tych podmiotów [Frączkiewicz-Wronka, 2013]. Współczesne zarządzanie publiczne łączy podejście klasycznej administracji z rynkowym i samoorganizacją [Kowalczyk, 2008]. Jednym z wyzwań zarządzania publicznego jest wypracowanie nowych wzorców funkcjonowania administracji publicznej. Potrzeba ta wynika także z aspiracji i oczekiwań obywateli, które zmieniają tradycyjne rozumienie interesu publicznego i standardów rządzenia [Szczupaczyński, 2015]. Istnieje więc potrzeba zastąpienia tradycyjnego modelu administracji publicznej administracją zorientowaną na osiąganie rezultatów oraz przekonanie, że instrumenty zarządzania stosowane w sektorze prywatnym mogą być skutecznie wykorzystane w sektorze publicznym. Do warunków zaistnienia administracji zorientowanej na osiąganie rezultatów zaliczyć można m.in.: elastyczną politykę kadrową, wprowadzenie systemu wynagradzania urzędników służby cywilnej według kryteriów efektywności działania, precyzyjne określenie celów i zadań instytucji publicznych oraz wypracowanie mierników służących ocenie ich realizacji [Kudłacz, Mazur-Kurach, 
2015, s. 54]. Pojawia się więc pytanie, w jakim zakresie wdrożenie koncepcji nowego zarządzania publicznego mogłoby usprawnić działania samorządowych kolegiów odwoławczych?

\section{Samorządowe kolegia odwoławcze w Polsce}

Samorządowe kolegia odwoławcze powstały 6 grudnia 1994 r. w wyniku przekształcenia kolegiów odwoławczych działających przy sejmikach samorządowych, na podstawie art. 29 Ustawy z dnia 12 października 1994 r. o samorządowych kolegiach odwoławczych [Karwicki, 2012; Ustawa, 1994]. Sprawują kontrolę instancyjną i nadzór pozainstancyjny w sprawach indywidualnych, rozstrzyganych przez organy jednostek samorządu terytorialnego oraz wykonują inne zadania określone ustawą o samorządowych kolegiach odwoławczych. Realizują zatem konstytucyjne prawo do zaskarżania orzeczeń i decyzji wydanych w pierwszej instancji [Konstytucja, art. 78].

Podstawę prawną działania samorządowych kolegiów odwoławczych w Polsce stanowi Ustawa z dnia 12 października 1994 r. o samorządowych kolegiach odwoławczych (tekst jedn. Dz.U. z 2015 r., poz. 1659, z późn. zm.) oraz akty wykonawcze, w tym m.in. Rozporządzenie Prezesa Rady Ministrów z dnia 17 lutego 1999 r. w sprawie obszarów właściwości samorządowych kolegiów odwoławczych [Rozporządzenie, 1999a], Rozporządzenie Prezesa Rady Ministrów z dnia 8 września 1999 r. w sprawie maksymalnej liczby etatowych członków samorządowych kolegiów odwoławczych [Rozporządzenie, 1999b] oraz inne [Rozporządzenie, 2001; Rozporządzenie, 2002]. Ponadto kolegia działają na podstawie wewnętrznych regulaminów organizacyjnych.

Ustawa o samorządowych kolegiach odwoławczych [1994] nadała nowy kształt kolegiom, regulując ich ustrój, organizację wewnętrzną i zakres kompetencji, a także ujednolicając ich strukturę. Ustanowiła podstawę ich samodzielności organizacyjnej i finansowej oraz dała podstawy do samodzielnego i niezależnego działania [Sadowski, 2015; Zimmermann, 2015].

Samorządowe kolegium odwoławcze jest organem wyższego stopnia w indywidualnych sprawach z zakresu administracji publicznej należących do właściwości samorządu terytorialnego, właściwym do rozpatrywania odwołań od decyzji, zażaleń na postanowienia, żądań wznowienia postępowań lub stwierdzenia nieważności decyzji [Ustawa, 1994] w trybie uregulowanym przez przepisy Kodeksu postępowania administracyjnego (k.p.a.) [Ustawa, 1960] oraz Ustawy z dnia 29 sierpnia 1997 roku - Ordynacja podatkowa [Ustawa, 1997]. Kolegium orzeka również w innych sprawach określonych w odrębnych ustawach.

Kolegia są jednostkami budżetowymi i działają w obszarze swojej właściwości miejscowej, która odpowiada obszarowi właściwości miejscowej sądów administracyjnych pierwszej instancji. Obecnie funkcjonuje w Polsce 49 samorządowych kolegiów odwoławczych, co odpowiada podziałowi administracyjnemu, jaki obowiązywał od 1 czerwca 1975 r. do 31 grudnia 1998 r. 
W skład kolegium wchodzą prezes, wiceprezes oraz pozostali członkowie, a zatrudnienie w kolegium może mieć charakter etatowy lub pozaetatowy. Etatowym członkiem kolegium może być osoba, która ma obywatelstwo polskie i korzysta z pełni praw publicznych, a także ukończyła magisterskie studia prawnicze lub administracyjne. Ponadto wykazuje się wysokim poziomem wiedzy prawniczej w zakresie administracji publicznej oraz ma doświadczenie zawodowe i nie została skazana prawomocnym wyrokiem orzeczonym za przestępstwo popełnione z winy umyślnej [Ustawa, 1994].

Nadzór nad działalnością administracyjną kolegiów sprawuje Prezes Rady Ministrów, który ponadto powołuje lub odwołuje prezesa i członków kolegium, określa w drodze rozporządzenia szczegółowe zasady ich wynagradzania, obszar właściwości miejscowej oraz maksymalną liczbę członków etatowych.

$\mathrm{Na}$ podstawie ustawy o samorządowych kolegiach odwoławczych [Ustawa, 1994] zgromadzeni na wspólnym posiedzeniu prezesi kolegiów tworzą, z mocy prawa, Krajową Reprezentację Samorządowych Kolegiów Odwoławczych. Do zadań tego zgromadzenia należą m.in. wymiana doświadczeń w zakresie organizacji i funkcjonowania kolegiów oraz działalności orzeczniczej, opiniowanie aktów prawnych i postępowania administracyjnego oraz podejmowanie uchwał w innych istotnych sprawach dotyczących kolegiów.

Orzeczenia kolegium zapadają po przeprowadzeniu rozprawy lub na posiedzeniu niejawnym $\mathrm{i}$ wydawane są $\mathrm{w}$ formie decyzji lub postanowień (z zastrzeżeniem wybranych artykułów Ustawy z dnia 21 sierpnia 1997 r. o gospodarce nieruchomościami [Ustawa, 1997]). Kontrolę orzecznictwa kolegiów sprawuje sąd administracyjny na zasadach i w trybie określonym przepisami Ustawy z dnia 25 lipca 2002 r. Prawo o ustroju sądów administracyjnych [Ustawa, 2002]. Kolegium orzeka w składzie trzyosobowym, chyba że przepisy szczególne stanowią inaczej. Orzeczenia zapadają większością głosów. Składowi orzekającemu przewodniczy prezes lub etatowy członek kolegium.

\section{Materiały i metody}

Materiał wyjściowy do analizy stanowiły informacje roczne z działalności samorządowych kolegiów odwoławczych w latach 2012-2015. Okres ten wybrano z uwagi na relatywnie dobrą dostępność sprawozdań na stronach internetowych Biuletynów Informacji Publicznej.

Szczegółowej analizie poddano łącznie 196 raportów. Z każdego z nich wynotowano m.in. stan zatrudnienia i wykształcenia pracowników oraz rodzaj i liczbę rozpatrywanych spraw. Dane zgromadzono w systemie informacji przestrzennej, który wykorzystano do ich prezentacji w odniesieniu przestrzennym. Ponadto wyliczono i przeanalizowano wskaźniki:

1. pozostałości WP (tzw. wskaźnik trwania postępowania) - odniesienie procentowe liczby spraw pozostających do załatwienia w danym okresie sprawozdawczym do przeciętnego miesięcznego wpływu w danym okre- 
sie sprawozdawczym lub w okresie działania jednostki organizacyjnej. Wskaźnik ten pokazuje, ile czasu (liczonego w miesiącach) potrzeba na likwidację pozostałości;

2. opanowania wpływu WOW - odniesienie liczby spraw załatwionych w danym okresie sprawozdawczym, lub okresie działania jednostki organizacyjnej, do liczby spraw wpływających. Wskaźnik opanowania wpływu o wartości mniejszej od 100 oznacza, że w danym roku załatwiono mniej spraw, niż ich wpłynęło;

3. załatwialności $\mathrm{WZ}$ - odniesienie procentowe liczby spraw załatwionych do liczby spraw do załatwienia, będących sumą wpływu i spraw niezałatwionych pozostających z poprzedniego okresu sprawozdawczego;

4. stopę załatwialności SZ - odniesienie procentowe liczby spraw pozostających do załatwienia w danym okresie sprawozdawczym do liczby spraw, które wpłynęły w danym okresie sprawozdawczym - jeżeli wynosi np. $15 \%$, to oznacza, że liczba spraw niezałatwionych stanowi 15\% liczby spraw wpływających w danym roku [NIK, 2010; Informacja statystyczna, 2012].

\section{Wyniki badań}

Liczba spraw ogółem, obejmująca sprawy pozostałe do rozpatrzenia z poprzedniego roku oraz sprawy wpływające, odnotowanych w samorządowych kolegiach odwoławczych w latach 2012-2015 jest znacząca i przekroczyła w skali kraju $1 \mathrm{mln}$. Kolegia rozpatrzyły w okresie 4 lat prawie 722 tys. spraw ogółem (średnio nieco ponad 180 tys. spraw rocznie w skali kraju), z czego większość to sprawy administracyjne - w analizowanym okresie odnotowano wpływ 662 tys. takich spraw, spośród których największą grupę stanowiły te z zakresu pomocy społecznej, świadczeń rodzinnych i zaliczek alimentacyjnych, oświaty, dodatków mieszkaniowych i spraw socjalnych (nieco ponad 20\% ogółu spraw administracyjnych). W dalszej kolejności znalazły się sprawy objęte proceduralnie przepisami ordynacji podatkowej. Najmniej spraw odnotowano z zakresu działalności gospodarczej. Ponadto, w porównaniu z rokiem 2012, znacząco wzrosła liczba spraw z zakresu ochrony środowiska, ochrony przyrody i ochrony zwierząt, a także odpadów i utrzymania porządku i czystości w gminach w 2015 roku odnotowano ich ponad 25\% więcej. W skali kraju zaobserwować można nieznaczny spadek wpływu spraw administracyjnych o nieco ponad $11 \%$ w stosunku do roku 2012.

Z wykluczeniem 2013 roku, kiedy to spraw ogółem w samorządowych kolegiach odwoławczych odnotowano w Polsce najwięcej, w latach 2014-2015 zauważyć można spadek ich liczby względem roku 2012 - w 2015 roku odnotowano około $7 \%$ spraw ogółem mniej niż w roku 2012. Najwięcej spraw ogółem odnotowano w województwach mazowieckim, wielkopolskim oraz śląskim. Najmniej w województwie opolskim (Rysunek 1). 

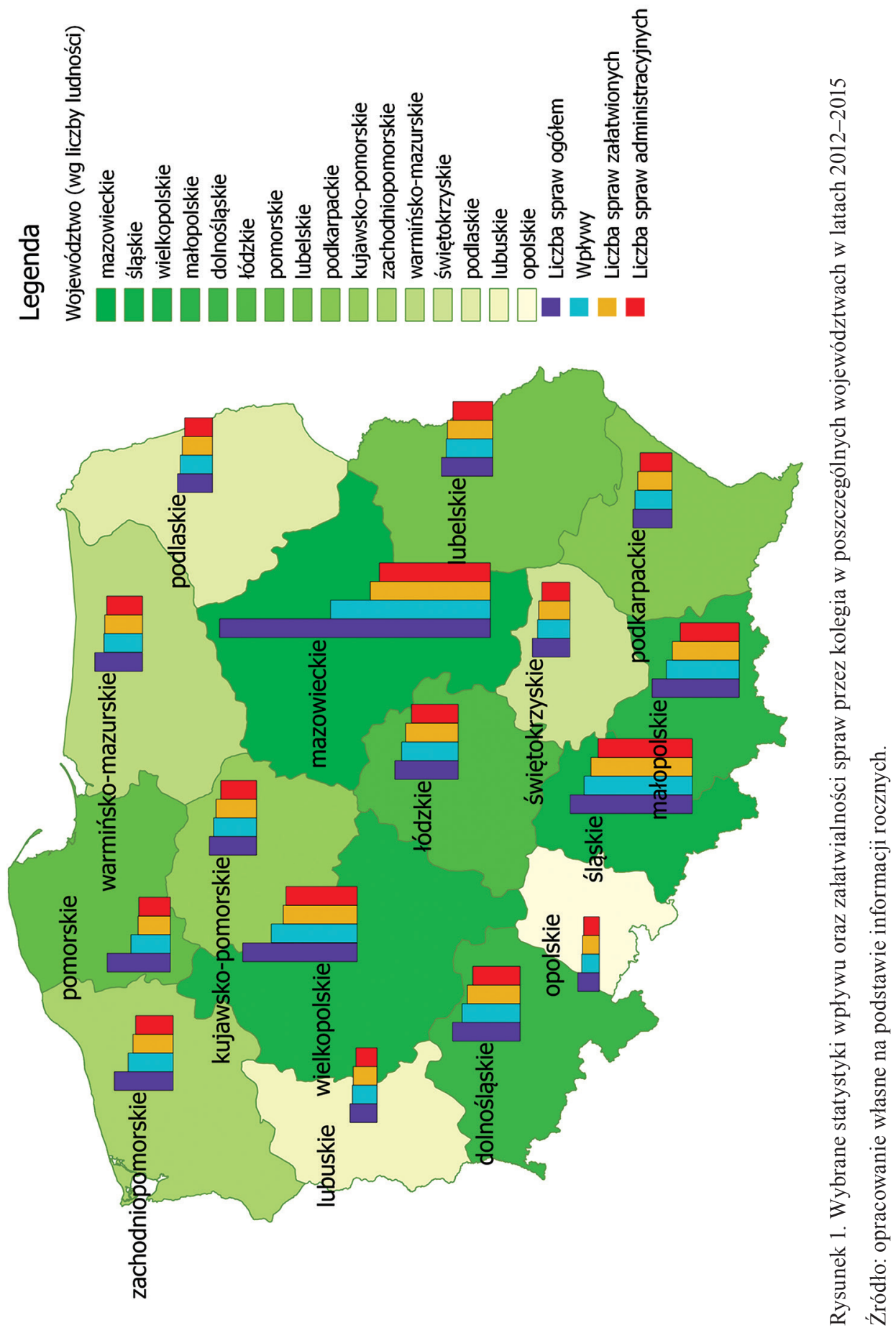
W skali Polski, we wszystkich województwach łącznie, porównując rok 2012 z rokiem 2015, zaobserwować można nieznacznie zmniejszającą się liczbę spraw wpływających do kolegiów (o 12\%), co jest zjawiskiem pozytywnym. Jedynie w województwie łódzkim odnotowano nieznaczny wzrost nowych spraw, który jednak w analizowanych latach utrzymywał się na zbliżonym poziomie.

Najwięcej spraw w latach 2012-2015 wpłynęło do samorządowych kolegiów odwoławczych województw: mazowieckiego, śląskiego, wielkopolskiego, małopolskiego, dolnośląskiego i łódzkiego. Najmniej - do kolegium w województwie opolskim. Województwo to ma jednak najmniejszą liczbę ludności spośród wszystkich.

Średnio w latach 2012-2015 obywatele oczekiwali 2,4 miesiąca (tj. około 73 dni) na załatwienie sprawy przez samorządowe kolegia odwoławcze (Tabela 1). Wskaźnik pozostałości (WP) sukcesywnie i konsekwentnie wzrastał od 2012 roku, co oznacza, że czas rozpatrywania spraw przez kolegia w skali Polski się wydłużył.

Tabela 1

Charakterystyka załatwialności spraw w kolegiach w latach 2012-2015

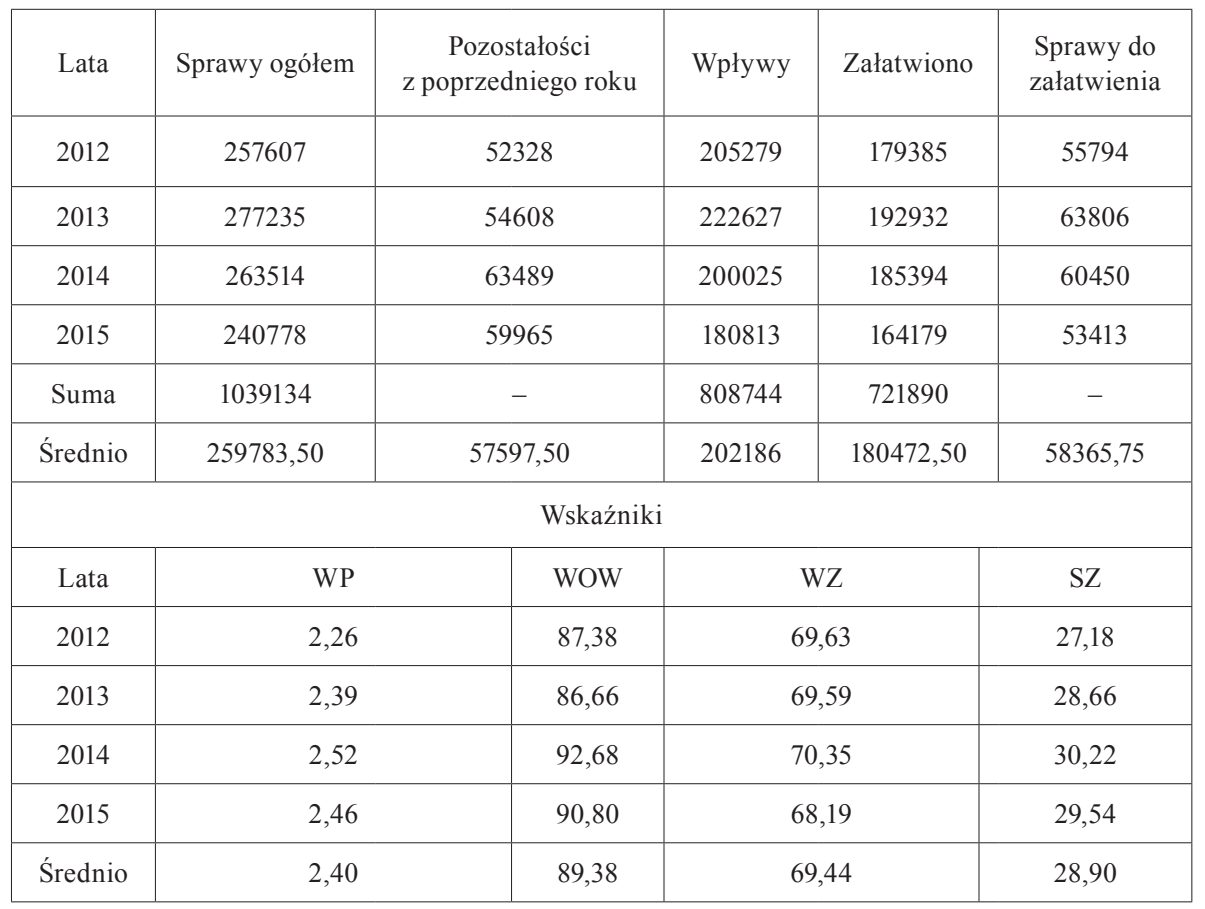

WP - wskaźnik pozostałości, WOW - wskaźnik opanowania wpływu, WZ - wskaźnik załatwialności, SZ - stopa załatwialności

Źródło: opracowanie własne na podstawie informacji rocznych. 
W latach 2012-2015 kolegia załatwiały średnio, w skali kraju, 89 na 100 spraw wpływających (wskaźnik opanowania wpływu WOW). Najtrudniejszym dla SKO rokiem w analizowanym okresie był rok 2013, kiedy to kolegia załatwiały średnio niecałe 87 na 100 spraw, należy jednak zauważyć, że w roku tym odnotowano najwięcej wpływów.

W 2014 roku kolegia odzyskały dynamikę działania, załatwiając nieco ponad $70 \%$ ogółu spraw ujętych w ewidencji (sprawy bieżące oraz zaległe, wskaźnik załatwialności WZ). Na koniec 2015 roku liczba spraw niezałatwionych stanowiła niecałe $30 \%$ spraw wpływających tego roku (stopa załatwialności SZ).

Średnio w latach 2012-2015 wskaźnik zaskarżalności spraw, liczony jako liczba skarg skierowanych do sądu w stosunku do ogólnej liczby podjętych przez kolegium rozstrzygnięć $\mathrm{w}$ roku objętym informacją podlegających zaskarżeniu, wyniósł około 13\%, przy czym największą średnią wartość uzyskał w 2014 roku (około 14,2\%), a najmniejszą w 2012 (około 11,5\%).

W 2015 roku w Polsce zatrudnionych było w kolegiach łącznie 588 pracowników na stanowiskach orzeczniczych (członkowie etatowi kolegiów), co stanowiło 585 pełnych etatów (Tabela 2). Spośród nich 518 legitymowało się wykształceniem wyższym prawniczym (ok. 87\%). Składy orzekające uzupełniane były przez 665 pracowników nieetatowych, spośród których $68 \%$ posiadało wykształcenie prawnicze. Kolegia w Polsce zatrudniły łącznie 449 osób na stanowiskach związanych z obsługą biur, co stanowiło 437,5 etatu.

Na przestrzeni lat stan zatrudnienia w kolegiach nie uległ większym zmianom, m.in. z uwagi na fakt, że pracownicy na etatach orzeczniczych są powoływani na czas nieokreślony. Pracownicy odwołani, składający rezygnację lub odchodzący na emeryturę, są w drodze konkursu uzupełniani nowymi.

Tabela 2

Zatrudnienie w samorządowych kolegiach odwoławczych w latach 2012-2015

\begin{tabular}{|c|c|c|c|c|c|c|c|}
\hline \multirow{2}{*}{ Lata } & \multicolumn{3}{|c|}{ Pracownicy etatowi } & \multicolumn{2}{c|}{ Pracownicy pozaetatowi } & \multicolumn{2}{c|}{ Pracownicy biurowi } \\
\cline { 2 - 8 } & $\begin{array}{c}\text { Liczba } \\
\text { osób }\end{array}$ & $\begin{array}{c}\text { Liczba } \\
\text { etatów }\end{array}$ & $\begin{array}{c}\text { Wykształcenie } \\
\text { prawnicze }\end{array}$ & $\begin{array}{c}\text { Liczba } \\
\text { osób }\end{array}$ & $\begin{array}{c}\text { Wykształcenie } \\
\text { prawnicze }\end{array}$ & $\begin{array}{c}\text { Liczba } \\
\text { osób }\end{array}$ & $\begin{array}{c}\text { Liczba } \\
\text { etatów }\end{array}$ \\
\hline 2012 & 596 & 582 & 516 & 665 & 456 & 456 & 441,20 \\
\hline 2013 & 597 & 590 & 518 & 640 & 440 & 457 & 445,35 \\
\hline 2014 & 590 & 585 & 509 & 657 & 443 & 448 & 435,55 \\
\hline 2015 & 588 & 584 & 511 & 686 & 469 & 449 & 437,50 \\
\hline
\end{tabular}

Źródło: opracowanie własne na podstawie informacji rocznych.

\section{Dostępność informacji publicznych}

Jednym z celów, jaki powinny realizować jednostki administracji publicznej, jest ułatwienie obywatelom dostępu do elektronicznych usług publicznych. Zgodnie z Rozporządzeniem Rady Ministrów z dnia 12 kwietnia 2012 roku w sprawie 
Krajowych Ram Interoperacyjności (KRI), minimalnych wymagań dla rejestrów publicznych i wymiany informacji w postaci elektronicznej oraz minimalnych wymagań dla systemów teleinformatycznych [Rozporządzenie, 2012, rozdz. IV, $\S 19]$ do końca maja 2015 roku wszystkie systemy teleinformatyczne podmiotów realizujących zadania publiczne, $\mathrm{w}$ tym serwisy internetowe, powinny być zgodne z wytycznymi WCAG 2.0 (ang. Web Content Accessibility Guidelines) na określonym poziomie [Król, 2016].

Ustawa z dnia 6 września 2001 r. o dostępie do informacji publicznej nakłada na podmioty administracji publicznej obowiązek udostępniania informacji za pomocą publikatora teleinformatycznego, zwanego Biuletynem Informacji Publicznej [Ustawa, 2001]. W trakcie kompletowania informacji rocznych odnotowano siedem różnych układów graficznych biuletynów, z czego trzy nie spełniały wymogów dostępności dla osób niepełnosprawnych [Rozporządzenie, 2012]. Zauważono także, że większość informacji rocznych, uchwał oraz postanowień wydanych przez kolegia opublikowano z pominięciem zasad dostępności, tj. w formie skanów złej jakości. Tak zamieszczone dokumenty mogą być nieczytelne dla osób z dysfunkcjami wzroku. Ponadto w kilkunastu przypadkach odnotowano brak sprawozdań rocznych $\mathrm{z}$ różnych lat. Wymagało to interwencji w biurach kolegiów w Koninie, Nowym Sączu, Częstochowie, Kaliszu, Kielcach, Lesznie, Opolu, Radomiu i Rzeszowie.

\section{Wnioski}

1. Pomimo że kolegia mają obowiązek publikowania informacji rocznych w Biuletynach Informacji Publicznej, w kilkunastu przypadkach odnotowano ich brak, co utrudniło ich skompletowanie. Ponadto miejsce i forma ich publikacji wymagają ujednolicenia.

2. Dynamiczny rozwój technologiczny, umożliwiający powszechny dostęp do informacji, oraz towarzyszące mu przemiany społeczno-gospodarcze wpływają na wzrost świadomości obywatelskiej. Skutkuje to nowymi wyzwaniami stawianymi przed organizacjami sektora publicznego [Konieczny, 2014]. Problem dostępności oraz technicznej jakości informacji rocznych mogłaby rozwiązać aplikacja internetowa utworzona z myślą o ich publikacji, z modułem generowania zestawień zbiorczych i ich wizualizacji w odniesieniu przestrzennym. Informacje roczne byłyby w tym przypadku generowane $\mathrm{w}$ jednym formacie, bezpośrednio $\mathrm{z}$ bazy danych. Ułatwiłoby to (zautomatyzowało) generowanie statystyk ogólnopolskich oraz wpłynęło na polepszenie dostępności danych.

3. W okresie 2012-2015 zaobserwować można było wahania liczby spraw wpływających do kolegiów odwoławczych, co mogło być związane ze zmianami w prawodawstwie, np. w zakresie ustawy o utrzymaniu czystości i porządku w gminach [Ustawa, 1996]. W opinii autorów badań w kolejnych latach prognozować można wpływ spraw utrzymujący się na poziomie około 200 tys. rocznie. 
4. Samorządowe kolegia odwoławcze, jako jednostki administracji publicznej, zmagają się z licznymi problemami, w tym natury menedżerskiej. W analizowanym okresie składy orzekające kolegiów poświęcały coraz więcej czasu na załatwienie sprawy. Zgłaszały przy tym (w części opisowej informacji rocznych) coraz większy stopień skomplikowania spraw, problemy lokalowe i braki kadrowe.

\section{Podsumowanie}

Samorządowe kolegia odwoławcze rozpatrują każdego roku znaczną liczbę spraw z zakresu administracji publicznej, należących do właściwości samorządu terytorialnego, w tym odwołań od decyzji, zażaleń na postanowienia, żądań wznowienia postępowań lub stwierdzenia nieważności decyzji. Rozstrzygają również $\mathrm{w}$ innych sprawach określonych w odrębnych ustawach. Kolegia są swoistym gwarantem ochrony praw obywateli, a także realizacji prawa do dobrej administracji. Codzienna praca kolegiów w Polsce to tysiące rozpatrzonych spraw oraz znaczący dorobek orzeczniczy, często w zakresie spraw bezprecedensowych.

Przeprowadzona analiza prezentuje jedynie stopień, w jakim samorządowe kolegia odwoławcze są obciążone pracą oraz, w pewnym zakresie, efektywność realizacji powierzonych im zadań. Trudno na ich podstawie wysunąć wnioski co do podejmowanych w kolegiach działań zarządczych oraz możliwości usprawnienia pracy kolegiów. Analiza literatury oraz poczynione obserwacje pozwalają jednak stwierdzić, że samorządowe kolegia odwoławcze powinny, oprócz administrowania skoncentrowanego głównie na aspektach prawnych, skupić się także na zarządzaniu nakierowanym na odbiorcę usług publicznych. Wykorzystanie metod zarządzania przeniesionych z praktyki zarządzania przedsiębiorstwami może mieć bezpośrednie przełożenie na liczbę rozpatrywanych spraw oraz jakość wydawanych orzeczeń. W świetle ograniczonych zasobów, jakimi dysponują, może to mieć wpływ na podniesienie ogólnej sprawności ich działania.

\section{Bibliografia}

Cyfert S., Dyduch W., Latusek-Jurczak D., Niemczyk J., Sopińska A. (2014), Subdyscypliny w naukach o zarzadzaniu - logika wyodrębnienia, identyfikacja modelu koncepcyjnego oraz zawartość tematyczna, „Organizacja i Kierowanie”, 1(161).

Frączkiewicz-Wronka A. (2013), Wstęp, „Zarządzanie publiczne: koncepcje, metody, techniki”, Wydawnictwo Uniwersytetu Ekonomicznego w Katowicach, Katowice.

Glińska B., Kuc B.R., Szczepankowski P. (1996), Zarządzanie strategiczne-geneza, rozwój, priorytety, Wydawnictwo Key Text, Warszawa. 
Glumińska-Pawlic J. (2003), Samodzielność samorządu terytorialnego w Polsce, Wydawnictwo Uniwersytetu Śląskiego, Katowice.

Informacja statystyczna (2012), Informacja statystyczna o ewidencji spraw i orzecznictwie w sadach powszechnych oraz o więziennictwie. Podstawowe wskaźniki statystyczne przedstawiajace osiagnięcia $w$ załatwialności spraw w sadach powszechnych $w 2011$ roku w porównaniu z danymi za lata 2007-2010. DO-II-0320-1/12. Departament Organizacyjny, Wydział Statystyki, Warszawa.

Izdebski H. (2007), Od administracji publicznej do public governance, „Zarządzanie Publiczne", 1.

Karwicki T. (2012), Samorządowe kolegium odwoławcze jako kolegialny organ administracji publicznej, „Acta Universitatis Lodziensis. Folia Oeconomica”, 270.

Konieczny M. (2014), Przykłady wykorzystania metodyk typu Agile w zarzadzaniu projektami w sektorze publicznym, „Zarządzanie Publiczne”, 28(4).

Konstytucja Rzeczypospolitej Polskiej z dnia 2 kwietnia 1997 r., Dz.U. z 1997 r., nr 78, poz. 483.

Kowalczyk L. (2008), Współczesne zarządzanie publiczne jako wynik procesu zmian w podejściu do administracji publicznej, „Zeszyty Naukowe Wałbrzyskiej Wyższej Szkoły Zarządzania i Przedsiębiorczości”, 11(1).

Kożuch B. (2004), Zarządzanie publiczne. W teorii i praktyce polskich organizacji, Placet, Warszawa.

Kożuch B. (2005), Zarządzanie publiczne jako dyscyplina naukowa. „Zarządzanie Publiczne”, 1.

Król K. (2016), Audyt dostępności witryn internetowych małopolskich gmin wiejskich, „Roczniki Naukowe Ekonomii Rolnictwa i Rozwoju Obszarów Wiejskich”, 103(1).

Kudłacz M., Mazur-Kurach P. (2015), Formy zarządzania publicznego w kontekście rozwoju miast w Polsce, „Zarządzanie Publiczne”, 4 (34).

Miłek K. (2015), Rola Samorządowych kolegiów odwoławczych w kontekście realizacji zadań jednostek samorzadu terytorialnego [w:] S. Gwoździewicz, B. Mydłowska (red.), Prawne i społeczne problemy samorzadu terytorialnego, Wyższa Szkoła Przedsiębiorczości w Warszawie, Warszawa.

NIK (2010), Wystapienie pokontrolne Najwyższej Izby Kontroli, LKA-4101-2103/2010/P/10/083.

Olejniczak K. (2009), Ku diagnozie polskiej administracji rządowej. Kontekst, potrzeby informacyjne, perspektywy, „Zarządzanie Publiczne”, 1(7).

Rozporządzenie Prezesa Rady Ministrów z dnia 17 lutego 1999 r. w sprawie obszarów właściwości samorządowych kolegiów odwoławczych, Dz.U. z 1999 r., nr 13, poz. 115.

Rozporządzenie Prezesa Rady Ministrów z dnia 8 września 1999 r. w sprawie maksymalnej liczby etatowych członków samorządowych kolegiów odwoławczych, Dz.U. z 1999 r., nr 74, poz. 828.

Rozporządzenie Prezesa Rady Ministrów z dnia 16 lutego 2001 r. w sprawie szczegółowych zasad i trybu postępowania wyjaśniającego i postępowania dyscyplinarnego wobec członków samorządowego kolegium odwoławczego oraz wykonywania kar dyscyplinarnych i ich zatarcia, Dz.U. z 2001 r., nr 14, poz. 125.

Rozporządzenie Prezesa Rady Ministrów z dnia 1 lipca 2002 r. w sprawie wielokrotności kwoty bazowej oraz szczegółowych zasad wynagradzania prezesa, wiceprezesa, pozostałych członków samorządowego kolegium odwoławczego i pracowników biura tego kolegium, Dz.U. z 2002 r., nr 109, poz. 960 ze zm. 
Rozporządzenie Rady Ministrów z dnia 12 kwietnia 2012 r. w sprawie Krajowych Ram Interoperacyjności, minimalnych wymagań dla rejestrów publicznych i wymiany informacji w postaci elektronicznej oraz minimalnych wymagań dla systemów teleinformatycznych, Dz.U. z 2012 r., poz. 526.

Sadowski P. (2015), Działalność orzecznicza samorzadowych kolegiów odwoławczych a dwuinstancyjne postepowanie sadowo-administracyjne. Rozważania nad racja bytu samorzadowych kolegiów odwoławczych, „Przegląd Prawa Konstytucyjnego”, 5(27).

Satoła Ł. (2010), Ocena sytuacji finansowej gmin wiejskich w Polsce w latach 2006-2008, „Acta Sci. Pol. Ser. Oeconomica”, 9(2).

Skibiński A. (2009), Pozycja ustrojowa samorządowego kolegium odwoławczego, „PWSZ IPiA Studia Lubuskie", V.

Skibiński A. (2008), Regionalne Izby Obrachunkowe i Samorzadowe Kolegia Odwoławczetypowe organy administracji czy wyspecjalizowana administracja wojewódzka?, „PWSZ IPiA Studia Lubuskie", IV.

Sudoł S. (2013), Nauki o zarządzaniu a zarządzanie publiczne, „Studia Ekonomiczne”, 169.

Szczupaczyński J. (2015), Między utopia a pragmatyzmem - w poszukiwaniu koncepcyjnych podstaw zarządzania przez wartości w administracji publicznej, ,Zarządzanie Publiczne", 31(3).

Szumowski W. (2014). Zarządzanie publiczne - próba systematyzacji koncepcji, „Nauki o Zarządzaniu", 4(21).

Ustawa z dnia 14 czerwca 1960 r. Kodeks postępowania administracyjnego, tekst jedn. Dz.U. z 2016 r., poz. 23, z późn. zm.

Ustawa z dnia 12 października 1994 r. o samorządowych kolegiach odwoławczych, tekst jedn. Dz.U. z 2015 r., poz. 1659, z późn. zm.

Ustawa z dnia 13 września 1996 r. o utrzymaniu czystości i porządku w gminach, tekst jedn. Dz.U. z 2016 r., poz. 250, z późn. zm.

Ustawa z dnia 21 sierpnia 1997 r. o gospodarce nieruchomościami, tekst jedn. Dz.U. z 2015 r., poz. 1774 , z późn. zm.

Ustawa z dnia 29 sierpnia 1997 r. - Ordynacja podatkowa, tekst jedn. Dz.U. z 2017 r., poz. 201, z późn. zm.

Ustawa z dnia 6 września 2001 r. o dostępie do informacji publicznej, tekst jedn. Dz.U. z 2015 r., poz. 2058, z późn. zm.

Ustawa z dnia 25 lipca 2002 r. Prawo o ustroju sądów administracyjnych, tekst jedn. Dz.U. z 2014 r., poz. 1647, z późn. zm.

Zimmermann J. (2015), Jurysdykcyjna ranga samorządowych kolegiów odwoławczych, „Ruch Prawniczy, Ekonomiczny i Socjologiczny”, 77(3).

Ziniewicz M.A. (2010), Decyzja administracyjna w ustawie o gospodarce nieruchomościami, „Studia i Materiały Towarzystwa Naukowego Nieruchomości”, 18(4). 